\title{
Origin and Evolution of Plastids and Photosynthesis in Eukaryotes
}

\author{
Geoffrey I. McFadden \\ School of Botany, University of Melbourne, Victoria 3010, Australia \\ Correspondence: gim@unimelb.edu.au
}

Recent progress in understanding the origins of plastids from endosymbiotic cyanobacteria is reviewed. Establishing when during geological time the endosymbiosis occurred remains elusive, but progress has been made in defining the cyanobacterial lineage most closely related to plastids, and some mechanistic insight into the possible existence of cryptic endosymbioses perhaps involving Chlamydia-like infections of the host have also been presented. The phylogenetic affinities of the host remain obscure. The existence of a second lineage of primary plastids in euglyphid amoebae has now been confirmed, but the quasipermanent acquisition of plastids by animals has been shown to be more ephemeral than initially suspected. A new understanding of how plastids have been integrated into their hosts by transfer of photosynthate, by endosymbiotic gene transfer and repatriation of gene products back to the endosymbiont, and by regulation of endosymbiont division is presented in context.

$P^{\mathrm{h}}$ hotosynthesis is biology's equivalent of alchemy converting a common substance $\left(\mathrm{CO}_{2}\right)$ into a precious one (reduced carbon compounds rich in chemical energy). Freely available light energy is initially converted to precious chemical energy in the form of ATP. This energy, and the reducing power generated by splitting water molecules to release electrons, is used to fix carbon from atmospheric $\mathrm{CO}_{2}$ and generate reduced carbon compounds that underpin the biosphere. It is estimated that plants and algae convert 258 billion tons of carbon dioxide into biomass by photosynthesis annually (Geider et al. 2001). Microfossils in ancient stromatolites indicate that cyanobacterium-like organisms had invented this process — or an early, perhaps nonoxygenic, version of it-at least 3.5 byo (billions of years old) (Lowe 1980; Wal- ter et al. 1980; Schopf 1993). These photosynthetic prokaryotes substantially predate eukaryotes, which emerged much later (Rasmussen et al. 2008; Koonin 2010). The common ancestor of all eukaryotes entered into an endosymbiotic partnership with an $\alpha$-proteobacterium that evolved into the mitochondrion, now the site of aerobic respiration in most eukaryotes (Gray 2012); animals and fungi are heterotrophic descendants of this partnership. Another lineage, which eventually produced the plants, entered into a second endosymbiotic partnership, this time with a cyanobacterium, which transplanted photosynthetic alchemy into eukaryotes to create plastids (Gray and Archibald 2012). This review will highlight recent progress in our understanding of the origin and evolution of plastids.

Editors: Patrick J. Keeling and Eugene V. Koonin

Additional Perspectives on The Origin and Evolution of Eukaryotes available at www.cshperspectives.org

Copyright (C) 2014 Cold Spring Harbor Laboratory Press; all rights reserved; doi: 10.1101/cshperspect.a016105

Cite this article as Cold Spring Harb Perspect Biol 2014;6:a016105 
G.I. McFadden

\section{THE ENDOSYMBIONT: WHEN AND WHO?}

The notion that plastids trace their ancestry back to cyanobacteria dates back 130 years when Schimper first noted similarities (Schimper 1883). However, in that time we have struggled to (i) identify exactly which of the cyanobacteria a plastid is most closely related to, and (ii) determine when the endosymbiont and its host entered into partnership. The obvious antiquity of plastid endosymbiosis makes these issues difficult to resolve. Dating plastid endosymbiotic origin has been contentious. Fossil evidence for early eukaryotic algae is open to varied interpretation; after all we cannot see from their rock impressions whether these organisms actually had a nucleus or a plastid. The oldest fossils argued to be eukaryotic algae are Grypania at 2.1 byo (Han and Runnegar 1992), Bangiomorpha at 1.2 byo (Butterfield et al. 1990), and a collection of acritarchs, which might be dinoflagellates, at 1.2-1.5 byo (Meng et al. 2005). We thus have a window, depending on which of these - if any-you accept as the first eukaryotic alga, of $\sim 1$ billion years for the origin of plastids. Also, considering that dinoflagellates undoubtedly harbor a secondary endosymbiont and must postdate the initial primary endosymbiotic acquisition of a cyanobacterium, the acritarchs confound the timing even further. Molecular clock approaches to dating plastid endosymbiosis are similarly fraught. Fossil dated phylogeny identifies a window between 1.4 and 1.7 byo (Parfrey et al. 2011), whereas use of cross-calibrated Bayesian estimates from duplicated ATP synthase genes puts the acquisition of plastids as recently as 0.9 byo (Shih and Matzke 2013).

Phylogenies incorporating plastids and cyanobacteria have positioned plastids alternatively at the base of the cyanobacterial radiation (Criscuolo and Gribaldo 2011), as sister to coccoid cyanobacteria (Reyes-Prieto et al. 2010), with the heterocyst-forming, nitrogen-fixing Cyanothece clade (Deschamps et al. 2008), or with filamentous, heterocyst-forming cyanobacterial lineages (Deusch et al. 2008). An acknowledged problem with this question is the confounding lateral gene transfer among cyanobacteria post- endosymbiosis. To circumvent this problem Dagan et al. (2013) compare gene inventories, finding plastids share the most genes with filamentous, heterocyst-forming bacteria. They argue that nitrogen fixation, along with the alchemy of photosynthesis, was an early driver for endosymbiosis but became less important to the partnership with increasing nitrate abundance (Dagan et al. 2013).

The overwhelming majority of plastid encoded genes, and endosymbiont genes relocated to the host nucleus have cyanobacterial signatures (Deusch et al. 2008), but a small cadre of genes show remarkable similarity to homologs from the pathogenic bacteria belonging to the chlamydiales (Stephens et al. 1998; Brinkman et al. 2002; Huang and Gogarten 2007; Colleoni et al. 2010; Price et al. 2012; Ball et al. 2013) leading to suggestions that in addition to its cyanobacterial endosymbiont that eventually evolved into plastids, the early eukaryote also hosted a Chlamydia-like pathogen that contributed genes to the host nucleus. Martin (2012) has argued strongly that the noncyanobacterial signals in plastid protein genes should be viewed through the prism of prokaryotic lateral gene transfer, proposing that the endosymbiont had likely undergone substantial reticulated gene evolution before entering its new niche inside a eukaryote. Indeed, exhaustive analysis reveals a mosaic of prokaryotic signals from right across the diversity of bacteria in the plant genome, probably introgressed by the cyanobacterial endosymbiont after it had experienced numerous lateral gene transfers (Dagan et al. 2013). Clearly we need to come to grips with lateral gene transfers in cyanobacteria both before and after they entered into endosymbiosis, which further emphasizes the need to know when and who.

Recently a mechanistic rationalization of the cryptic Chlamydia-like endosymbiont hypothesis was put forward (Colleoni et al. 2010; Ball et al. 2013). Dubbed the ménage à trois hypothesis (Baum 2013), the idea is based around storage by the host of carbohydrates procured from the photosynthetic endosymbiont. In a nutshell, the ménage à trois hypothesis posits that Chlamydia-like infection of the eukaryote host preadapted it to take better advantage of a cya- 
nobacterial endosymbiont by facilitating assimilation of a photosynthetic endosymbiont. Ball et al. (2013) point out that cyanobacteria store excess photosynthate as glycogen, which they polymerize from ADP-glucose monomers. Eukaryotes also store glycogen, but they normally build it up from UDP-glucose with enzymes that do not recognize other nucleotide sugars like ADP-glucose. Therefore a eukaryotic host might have had a problem if its cyanobacterial endosymbiont was donating ADP-glucose because it would be unable to efficiently modify or store the purloined photosynthate. However, if the host could make use of Chlamydia genes encoding ADP-glucose-friendly enzymes, cyanobacterial endosymbiosis might have been enhanced (Ball et al. 2013).

As with all preadaptation scenarios, the problem lies in the lack of positive selection for the preadaptation before the acquisition of a symbiont. In other words, why would the eukaryote maintain a suite of unusable ADP-glucose-modifying enzyme genes acquired by lateral gene transfer from a Chlamydia-like parasite until it also acquired a cyanobacterial endosymbiont? But, according to Ball et al. (2013), there is a neat solution to this paradox. They argue that the eukaryotic host did not initially acquire the genes from its Chlamydia infection, just the enzymes. Ball et al. (2013) argue that Chlamydialike parasites secrete ADP-glucose-modifying enzymes into their hosts to manipulate their carbohydrate processing in ways favorable to the parasite. This subjugation of host sugar usage by a parasite had the effect of preadapting the host to successful hosting of a photosynthetic cyanobacterium because its cytosol contained a suite of enzymes able to use prokaryote-like nucleotide sugars (Ball et al. 2013). Gene transfer from pathogen to host would then have been selected for if it favored endosymbiosis with a cyanobacterium-like partner.

\section{PAULINELLA-RETHINKING THE SINGULARITY OF PLASTID ORIGIN}

Dogma has it that a primary endosymbiosis between eukaryotic host and a cyanobacterial endosymbiont to create a plastid occurred (or survived) just once. However, new data on a little known euglyphid amoeba known as Paulinella has dismantled this paradigm. Paulinella chromatophora is a testate amoebae described in the 19th century by Robert Lauterborn (Lauterborn 1895). The genus name commemorates his aunt (Melkonian and Mollenhauer 2005), but even though Lauterborn knew he had found something significant, he could not anticipate just how important this organism is in endosymbiosis. The photosynthetic symbionts in Paulinella are highly reminiscent of cyanobacteria, right down to the peptidoglycan wall and division by binary fission (Kies 1974). The photosynthetic symbionts were originally known as chromatophores (Lauterborn 1895), but I believe they now have to be recognized as bona fide plastids - plastids with a separate origin to all others.

rRNA phylogeny confirmed the cyanobacterial source of chromatophores (Marin et al. $2005,2007)$. Sequencing of the chromatophore genome revealed massive reduction in comparison with free-living cyanobacteria; Paulinella chromatophores retain only $26 \%$ of the genes they would have originally possessed before entering into the endosymbiosis with the thecamoeba (Nowack et al. 2008). Genes for many crucial metabolic pathways including amino acid biosynthesis, cofactor biosynthesis, and the TCA cycle appear lost implying that they must have transferred to the thecamoeba host (Nowack et al. 2008), and transcriptomic analyses of nucleus-encoded genes corroborate endosymbiotic gene transfer (Nowack et al. 2011). Repatriation of endosymbiotically transferred genes' products (a series of photosystem I proteins) back to the chromatophores from the thecamoeba cytoplasm via the Golgi was recently shown (Nowack and Grossman 2012). We thus appear to have a parallel endosymbiotic generation of a plastid. Understanding how the host solved the problem of targeting proteins to the symbiont is the next challenge in this system. It is estimated that the symbiosis between cyanobacterium and thecamoeba is little more than 60 myo (millions of years old) (Nowack et al. 2008), far more recent than the primary endosymbiosis spawning canonical primary plastids 


\section{G.I. McFadden}

(see above). The realization that a second example of primary plastid acquisition was living in the ponds and reservoirs around us was a revelation, one that not only challenges our definition of what a plastid is (Bhattacharya et al. 2007; Keeling and Archibald 2008; Nakayama and Archibald 2012), but also promises to shed new light on their origins.

\section{CRAWLING LEAVES}

Although the Paulinella plastid endosymbiosis will rewrite the textbooks, another case of plastid acquisition seems less well integrated than previously thought. Sacoglossan sea slugs sequester plastids from grazed algae into a modified zone of their gut (Rumpho et al. 2011; Pierce and Curtis 2012). Known as kleptoplastidy, this apparent xenotransfer of photosynthesis into animals has fascinated evolutionary biologists and creationists alike (Doyle 2010) and fueled the science fiction notion of creating photosynthetic humans (Agapakis et al. 2011). The plastid-containing slugs are able to live without food for many months, and the assumption has always been that the plastids supply the slug with photosynthate (Rumpho et al. 2011; Pierce and Curtis 2012). Moreover, the longevity of the plastids in the slug cells strongly suggested that the slugs were nurturing their stolen plastids, perhaps even with products from genes that the slugs had acquired from the alga (Rumpho et al. 2011; Pierce and Curtis 2012). Various efforts to identify slug nucleus-encoded proteins in these plastids never yielded definitive proof (Mujer et al. 1996; Rumpho et al. 2008; Pierce et al. 2009), and recent transcriptomic approaches now suggest that no successful endosymbiotic gene transfer between alga and slug has occurred (Wagele et al. 2011; Bhattacharya et al. 2013). Nevertheless, a counterclaim that slugs do indeed express genes acquired from algae based on the presence of some very low frequency transcripts has also been presented (Pierce et al. 2012).

\section{HOW TO TAME YOUR SYMBIONT}

Domesticating a photosynthetic symbiont requires three elements: tapping it for photosyn- thate, procuring genes to supply it with proteins, and regulating its division. Gaining access to the photosynthate is argued to be the first critical step of plastid acquisition (Weber et al. 2006). A key innovation is posited to have been the recruitment of host nucleotide sugar translocators into the photosynthetic symbiont inner membrane. These transporters are now known as plastidic phosphate translocators (pPTs) (Weber et al. 2006). pPTs occur in all known plastids and must thus have arisen early in the establishment of the endosymbiosis before divergence into the principle lines of algae (Weber et al. 2006; Weber and Osteryoung 2010). pPTs are also argued to be ideal for tapping photosynthate from an endosymbiont because they are antiporters (they counter exchange inorganic orthophosphate for phosphorylated carbon compounds) and their action would not upset the metabolic homeostasis in either host or symbiont such as might occur with unregulated unidirectional transport (Weber et al. 2006; Weber and Osteryoung 2010). The pPT family has diversified to exchange a wide selection of reduced carbon compounds to suit the metabolic needs of different plastids (even nonphotosynthetic), but always by counter exchange, further emphasizing the criticality of this principle (Weber and Linka 2011).

The cyanobacterial endosymbiont introduced a trove of genetic novelty into the host. Hosts have apparently picked through this trove like a bargain hunter at a trash and treasure outlet (Larkum et al. 2007) making both strategic acquisitions and apparently eclectic gene adoptions (Deusch et al. 2008; Martin 2012). Thanks to some clever experiments we have some good insight into how (mechanistically) this opportunity shopping occurred (Huang et al. 2003). What's more, we have even found a few instances in which the endosymbionts would seem to have shut up shop, all but ceasing to relinquish any further genes to their hosts (Lister et al. 2003; Smith et al. 2011; Curtis et al. 2012).

Modern plastids typically encode about 100-200 genes, but a free-living cyanobacterium encodes several thousand genes. Although many endosymbiont genes were apparently lost (the peptidoglycan synthesis genes for instance 
are only retained in the plastids of the glaucophytes), a large number of genes were transferred to the host nucleus (Martin et al. 1998; Martin 2003; Deusch et al. 2008). Transfer of genes was likely a selective advantage for several reasons. First, the endosymbionts-now locked up inside their host - effectively became a clonal line relinquishing any opportunity for genetic exchange (and hence purifying selection) with any population of relatives. Nonlethal mutations would have been free to accumulate in a scenario referred to as Muller's ratchet. Relocation of these genes to the sexual host nucleus would provide all the advantages of diploidy, recombination and purifying selection so it was presumably selected for. Transferring genes to the nucleus might also have removed them from potential damage by reactive oxygen species produced by the release and transfer of electrons during photosynthesis (Allen 2003). The transfer of DNA from endosymbiont to host nucleus has been reconstructed in tobacco plants in the laboratory and shown to be surprisingly frequent (Huang et al. 2003). Considering the time frame, it is not at all surprising that the majority of genes for plastid proteins are now nucleus encoded. Indeed, the question that now needs answering is why any genes are still encoded by plastids (Allen and Raven 1996; Allen 2003).

It is not exactly clear how DNA is released from the endosymbiont and then integrated into the host nucleus, but the favored model is rupture of the symbiont and random integration of pieces of endosymbiont DNA (apparently of all sizes) into host nuclei by nonhomologous end joining into chromosome breaks. Analyses of gene transfer frequencies in plants (which have multiple plastids) and Chlamydomonas (which has just one) have revealed interesting differences in the rate of transfer (Huang et al. 2003; Lister et al. 2003). Known as the "limited transfer window" hypothesis, this idea rationalizes the observed relationship between the number of endosymbionts and the frequency of endosymbiotic gene transfer to the host. Simply stated, hosts with multiple endosymbionts have more chance of successful DNA transfer to the nucleus than hosts with few or just one endosymbiont (Lister et al. 2003; Smith et al. 2011). Multiple endosymbionts means multiple potential donors, but, perhaps more importantly, it is also postulated that hosts with just a single endosymbiont would either not survive the catastrophe of symbiont rupture or at least lose their only endosymbiont and need to return to a solo existence again (Lister et al. 2003). The limited transfer principal even extends to DNA transfers between plastids and mitochondria (Smith 2011), and between nucleomorphs (endosymbiotic nuclei) and their host nucleus (Curtis et al. 2012). Puzzlingly, transfer of DNA, either mitochondrial or nuclear, into plastids is extremely rare (Rice and Palmer 2006; Smith 2011).

Once the gene for a plastid-essential protein has been duplicated into the host cell nucleus, several things can occur. If the gene is expressed, the cell might discover a use for it, and positive selection could ensue. Otherwise the gene will likely decay and disappear. In this way most transfers probably just disappear, but many symbiont-derived genes have been recruited for host functions (Martin and Schnarrenberger 1997). Another option is for the product of an acquired gene to be repatriated back to the compartment of origin - the plastid. This category is crucial in endosymbiosis because it permits loss of the gene in the endosymbiont, because this type of endosymbiotic gene transfer likely circumvents the various hazards to genes in plastids (see above) it would be selected for. Furthermore, it grants hosts greater control of their symbionts. It also serves to render the symbiont nonautonomous, likely preventing it from exiting the symbiosis and returning to a free-living state. Selection should favor such a lock-in mechanism if the partners have increased fitness as a unit compared with solo existences.

We now understand how nucleus-encoded gene products, either from host genes or from genes acquired by the host from its symbiont, are targeted to plastids. The canonical route uses an amino-terminal extension on the cargo protein that docks with a translocation apparatus able to thread the protein through two linked pores in the outer and inner membranes of two 


\section{G.I. McFadden}

membrane plastids (Shi and Theg 2013). The pores and their attendant proteins are known as the Toc (translocation outer chloroplast) and Tic (translocation inner chloroplast) complexes (Shi and Theg 2013); core components are preserved in all plastids and originate from both the cyanobacterial endosymbiont and the host (McFadden and van Dooren 2004; Kalanon and McFadden 2008; Price et al. 2012). Receptors on the outer plastid membrane identify the protein to be imported (usually by its amino terminus), but how recognition occurs is not known. The unfolded protein is then threaded through a $\beta$ barrel channel protein (Toc75), which is descended from porins of the cyanobacterial endosymbiont (Schleiff et al. 2003a,b) and subject to regulated degradation by the host to control plastid protein import (Ling et al. 2012). Until recently it was less clear what roles the different components of the Tic complex had, but it is now apparent that Tic22 acts as a chaperone to guide proteins, after they emerge from Toc75, across the space between the inner and outer membranes toward the channel in the Tic complex (Glaser et al. 2012; Tripp et al. 2012). The inner membrane pore complex has recently been isolated and shown to be a trimeric assembly of Tic214 (formerly Ycf1), Tic100, Tic56, and Tic20 (Kikuchi et al. 2013).

Plastids are passed down vertically through the generations. It therefore follows that plastids have to replicate before host cell division. Indeed, getting this replication of the endosymbionts regulated was a critical element for establishment of the partnership. If the endosymbionts replicate too quickly, they could take over the host; too slow and the host might divide without sufficient symbionts to deploy into daughter cells. Fine-tuning the division rate and mechanism was a vital innovation for permanent endosymbiosis. With the notable exception of the nonphotosynthetic plastids of apicomplexan parasites (Francia et al. 2012), all plastids appear to divide using a mechanism inherited from their cyanobacterial predecessors. A GTPase known as FtsZ (filament temperature-sensitive mutant $Z$ ) assembles into a ring (the Z-ring) at the plastid equator under the guidance of proteins known as Min D \& E (minicell) and is tethered to the inner envelope membrane via ARC6 (accumulation and replication of chloroplasts) (Basak and Møller 2012; Terbush et al. 2013). Assembly of the Zring results in recruitment of additional division components to the mid-plastid, including PARC6, PDV1 (plastid division), and PDV2, and the contractile ARC5/DRP5B (dynaminrelated protein) and $\mathrm{PD}$ ( plastid division) rings on the cytosolic/host side of the outer plastid membrane (Basak and Møller 2012; Terbush et al. 2013). Finally, FtsZ, ARC5/DRP5B, and the $\mathrm{PD}$ rings constrict the inner and outer envelope membranes dividing the plastid into two equal halves. In plants, a protein known as CLMP1 (clumped chloroplasts) has a postdivision role in separation of plastids into daughter cells (Yang et al. 2011). It has also emerged that very-long-chain fatty acids, which have an acyl chain length of more than 20 carbons, have a role in correct positioning of the Z-ring, perhaps by influencing the distribution of membrane components of the ring (Nobusawa and Umeda 2012).

Most of the known plastid division machinery clearly originates from homologous binary fission machinery in cyanobacteria, but some parts (ACR6, PARC6, PDV1 and 2, and DRP5B) are apparently of eukaryotic origin and thus represent the host exerting control of endosymbiont division by the addition of new components to the process (Basak and Møller 2012).

\section{CONCLUSION}

Approximately 2 billion years after cyanobacteria-like organisms had invented photosynthesis, they entered into an endosymbiotic partnership with a eukaryotic host and evolved into plastids creating an autotrophic line of nucleuscontaining cells that were powered by light. The host and symbiont are now intimately integrated, morphologically, genetically, and metabolically. Nevertheless, the endosymbionts remain partially autonomous, still encoding and expressing a small residue of genes that act in concert with a wide range of componentssome transferred to the host by endosymbiotic 
gene transfer, plus many invented by the hostthat enhance the partnership to power an extraordinary amalgam, the descendants of which underpin life on earth.

\section{ACKNOWLEDGMENTS}

Support for the Australian Research Council and the National Health and Medical Research Council is gratefully acknowledged.

\section{REFERENCES}

Agapakis CM, Niederholtmeyer H, Noche RR, Lieberman TD, Megason SG, Way JC, Silver PA. 2011. Towards a synthetic chloroplast. PLoS ONE 6: e18877.

Allen JF. 2003. The function of genomes in bioenergetic organelles. Philos Trans R Soc Lond B Biol Sci 358: $19-38$.

Allen J, Raven J. 1996. Free-radical-induced mutation vs redox regulation: Costs and benefits of genes in organelles. J Mol Evol: 482-492.

Ball SG, Subtil A, Bhattacharya D, Moustafa A, Weber AP, Gehre L, Colleoni C, Arias MC, Cenci U, Dauvillee D. 2013. Metabolic effectors secreted by bacterial pathogens: Essential facilitators of plastid endosymbiosis? Plant Cell 25: 7-21.

Basak I, Møller SG. 2012. Emerging facets of plastid division regulation. Planta 237: 389-398.

Baum D. 2013. The origin of primary plastids: A pas de deux or a menage a trois? Plant Cell 25: 4-6.

Bhattacharya D, Archibald JM, Weber AP, Reyes-Prieto A. 2007. How do endosymbionts become organelles? Understanding early events in plastid evolution. Bioessays 29: $1239-1246$.

Bhattacharya D, Pelletreau KN, Price DC, Sarver KE, Rumpho ME. 2013. Genome analysis of Elysia chlorotica egg DNA provides no evidence for horizontal gene transfer into the germ line of this kleptoplastic mollusc. Mol Biol Evol 30: 1843-1852.

Brinkman FS, Blanchard JL, Cherkasov A, Av-Gay Y, Brunham RC, Fernandez RC, Finlay BB, Otto SP, Ouellette BF, Keeling PJ, et al. 2002. Evidence that plant-like genes in Chlamydia species reflect an ancestral relationship between Chlamydiaceae, cyanobacteria, and the chloroplast. Genome Res 12: 1159-1167.

Butterfield NJ, Knoll AH, Swett K. 1990. A bangiophyte red alga from the Proterozoic of arctic Canada. Science 250: 104-107.

Colleoni C, Linka M, Deschamps P, Handford MG Dupree P, Weber AP, Ball SG. 2010. Phylogenetic and biochemical evidence supports the recruitment of an ADP-glucose translocator for the export of photosynthate during plastid endosymbiosis. Mol Biol Evol 27: 2691-2701.

Criscuolo A, Gribaldo S. 2011. Large-scale phylogenomic analyses indicate a deep origin of primary plastids within cyanobacteria. Mol Biol Evol 28: 3019-3032.
Curtis BA, Tanifuji G, Burki F, Gruber A, Irimia M, Maruyama S, Arias MC, Ball SG, Gile GH, Hirakawa Y, et al. 2012. Algal genomes reveal evolutionary mosaicism and the fate of nucleomorphs. Nature 492: 59-65.

Dagan T, Roettger M, Stucken K, Landan G, Koch R, Major P, Gould SB, Goremykin VV, Rippka R, Tandeau de Marsac N, et al. 2013. Genomes of Stigonematalean cyanobacteria (subsection $\mathrm{V}$ ) and the evolution of oxygenic photosynthesis from prokaryotes to plastids. Genome Biol Evol 5: 31-44.

Deschamps P, Colleoni C, Nakamura Y, Suzuki E, Putaux JL, Buleon A, Haebel S, Ritte G, Steup M, Falcon LI, et al. 2008. Metabolic symbiosis and the birth of the plant kingdom. Mol Biol Evol 25: 536-548.

Deusch O, Landan G, Roettger M, Gruenheit N, Kowallik KV, Allen JF, Martin W, Dagan T. 2008. Genes of cyanobacterial origin in plant nuclear genomes point to a heterocyst-forming plastid ancestor. Mol Biol Evol 25: $748-761$.

Doyle S. 2010. Photosynthetic sea slugs: An evolutionary enigma. J Creation 24: 10-12.

Francia ME, Jordan CN, Patel JD, Sheiner L, Demerly JL, Fellows JD, De Leon JC, Morrissette NS, Dubremetz J-F, Striepen B. 2012. Cell division in apicomplexan parasites is organized by a homolog of the striated rootlet fiber of algal flagella. PLoS Biol 10: e1001444.

Geider RJ, Delucia EH, Falkowski PG, Finzi AC, Grime JP, Grace J, Kana TM, La Roche J, Long SP, Osborne BA, et al. 2001. Primary productivity of planet earth: Biological determinants and physical constraints in terrestrial and aquatic habitats. Glob Change Biol 7: 849-882.

Glaser S, van Dooren GG, Agrawal S, Brooks CF, McFadden GI, Striepen B, Higgins MK. 2012. Tic22 is an essential chaperone required for protein import into the apicoplast. J Biol Chem 287: 39505-39512.

Gray MW. 2012. Mitochondrial evolution. Cold Spring Harb Perspect Biol 4: a011403.

Gray MW, Archibald JM. 2012. Origins of mitochondria and plastids. In Advances in photosynthesis and respiration (ed. Govindjee, Sharkey TD), Vol. 35, pp. 1-30. Springer, New York.

Han TM, Runnegar B. 1992. Megascopic eukaryotic algae from the 2.1-billion-year-old negaunee iron-formation, Michigan. Science 257: 232-235.

Huang J, Gogarten JP. 2007. Did an ancient chlamydial endosymbiosis facilitate the establishment of primary plastids? Genome Biol 8: R99.

Huang CY, Ayliffe MA, Timmis JN. 2003. Direct measurement of the transfer rate of chloroplast DNA into the nucleus. Nature 422: 72-76.

Kalanon M, McFadden GI. 2008. The chloroplast protein translocation complexes of Chlamydomonas reinhardtii A bioinformatic comparison of Toc and Tic components in plants, green algae and red algae. Genetics 179: 95-112.

Keeling PJ, Archibald JM. 2008. Organelle evolution: What's in a name? Curr Biol 18: R345-R347.

Kies L. 1974. Electron microscopical investigations on Paulinella chromatophora Lauterborn, a thecamoeba containing blue-green endosymbioints (cyanelles). Protoplasma 80: 69-89. 


\section{G.I. McFadden}

Kikuchi S, Bedard J, Hirano M, Hirabayashi Y, Oishi M, Ima M, Takase M, Ide T, Nakai M. 2013. Uncovering the protein translocon at the chloroplast inner envelope membrane. Science 339: 571-574.

Koonin EV. 2010. The origin and early evolution of eukaryotes in the light of phylogenomics. Genome Biol 11: 209.

Larkum AW, Lockhart PJ, Howe CJ. 2007. Shopping for plastids. Trends Plant Sci 12: 189-195.

Lauterborn R. 1895. Protozoenstudien: II. Paulinella chromatophora nov. gen., nov. spec. ein beschalter Rhizopode des Süsswassers mit blaugrünen chromatophoren-artigen Einschlüssen. Z. Wiss. Zool. 59: 537-544.

Ling Q, Huang W, Baldwin A, Jarvis P. 2012. Chloroplast biogenesis is regulated by direct action of the ubiquitinproteasome system. Science 338: 655-659.

Lister DL, Bateman JM, Purton S, Howe CJ. 2003. DNA transfer from chloroplast to nucleus is much rarer in Chlamydomonas than in tobacco. Gene 316: 33-38.

Lowe D. 1980. Stromatolites 3,400-myr old from the Archean of Western Australia. Nature 284: 441-443.

Marin B, Nowack EC, Melkonian M. 2005. A plastid in the making: Evidence for a second primary endosymbiosis. Protist 156: 425-432.

Marin B, Nowack EC, Glockner G, Melkonian M. 2007. The ancestor of the Paulinella chromatophore obtained a carboxysomal operon by horizontal gene transfer from a Nitrococcus-like $\gamma$-proteobacterium. BMC Evol Biol 7: 85.

Martin W. 2003. Gene transfer from organelles to the nucleus: Frequent and in big chunks. Proc Natl Acad Sci 100: 8612-8614.

Martin W. 2012. Modern endosymbiotic theory: Getting lateral gene transfer into the equation. $J$ Endocytobiosis Cell Res 23: 1-5.

Martin W, Schnarrenberger C. 1997. The evolution of the Calvin cycle from prokaryotic to eukaryotic chromosomes: A case study of functional redundancy in ancien pathways through endosymbiosis. Curr Genet 32: 1-18.

Martin W, Stoebe B, Goremykin V, Hansmann S, Hasegawa M, Kowallik K. 1998. Gene transfer to the nucleus and the evolution of chloroplasts. Nature 393: 162-165.

McFadden GI, van Dooren GG. 2004. Evolution: Red algal genome affirms a common origin of all plastids. Curr Biol 14: R514-R516.

Melkonian M, Mollenhauer D. 2005. Robert Lauterborn (1869-1952) and his Paulinella chromatophora. Protist 156: $253-262$.

Meng F, Zhou C, Yin L, Chen Z, Yauan X. 2005. The oldest known dinoflagellates: Morphological and molecular evidence from Mesoproterozoic rocks at Yongji, Shanxi Province. Chinese Sci Bull 50: 1230-1234.

Mujer CV, Andrews DL, Manhart JR, Pierce SK, Rumpho ME. 1996. Chloroplast genes are expressed during intracellular symbiotic association of Vaucheria litorea plastids with the sea slug Elysia chlorotica. Proc Natl Acad Sci 93: 12333-12338.

Nakayama T, Archibald JM. 2012. Evolving a photosynthetic organelle. BMC Biol 10: 35 .

Nobusawa T, Umeda M. 2012. Very-long-chain fatty acids have an essential role in plastid division by controlling Z-ring formation in Arabidopsis thaliana. Genes Cells 17: 709-719.
Nowack EC, Grossman AR. 2012. Trafficking of protein into the recently established photosynthetic organelles of Paulinella chromatophora. Proc Natl Acad Sci 109: 53405345.

Nowack EC, Melkonian M, Glockner G. 2008. Chromatophore genome sequence of Paulinella sheds light on acquisition of photosynthesis by eukaryotes. Curr Biol 18: 410-418.

Nowack EC, Vogel H, Groth M, Grossman AR, Melkonian M, Glockner G. 2011. Endosymbiotic gene transfer and transcriptional regulation of transferred genes in Paulinella chromatophora. Mol Biol Evol 28: 407-422.

Parfrey LW, Lahr DJ, Knoll AH, Katz LA. 2011. Estimating the timing of early eukaryotic diversification with multigene molecular clocks. Proc Natl Acad Sci 108: 1362413629.

Pierce SK, Curtis NE. 2012. Cell biology of the chloroplast symbiosis in sacoglossan sea slugs. Int Rev Cell Mol Biol 293: $123-148$.

Pierce SK, Curtis N, Schwartz J. 2009. Chlorophyll a synthesis by an animal using transferred algal nuclear genes. Symbiosis 49: 121-131.

Pierce SK, Fang X, Schwartz JA, Jiang X, Zhao W, Curtis NE, Kocot KM, Yang B, Wang J. 2012. Transcriptomic evidence for the expression of horizontally transferred algal nuclear genes in the photosynthetic sea slug, Elysia chlorotica. Mol Biol Evol 29: 1545-1556.

Price DC, Chan CX, Yoon HS, Yang EC, Qiu H, Weber AP, Schwacke R, Gross J, Blouin NA, Lane C, et al. 2012. Cyanophora paradoxa genome elucidates origin of photosynthesis in algae and plants. Science 335: 843-847.

Rasmussen B, Fletcher IR, Brocks JJ, Kilburn MR. 2008. Reassessing the first appearance of eukaryotes and cyanobacteria. Nature 455: 1101-1104.

Reyes-Prieto A, Yoon HS, Moustafa A, Yang EC, Andersen RA, Boo SM, Nakayama T, Ishida K, Bhattacharya D. 2010. Differential gene retention in plastids of common recent origin. Mol Biol Evol 27: 1530-1537.

Rice DW, Palmer JD. 2006. An exceptional horizontal gene transfer in plastids: Gene replacement by a distant bacterial paralog and evidence that haptophyte and cryptophyte plastids are sisters. BMC Biol 4: 31 .

Rumpho ME, Worful JM, Lee J, Kannan K, Tyler MS, Bhattacharya D, Moustafa A, Manhart JR. 2008. Horizontal gene transfer of the algal nuclear gene $p s b \mathrm{O}$ to the photosynthetic sea slug Elysia chlorotica. Proc Natl Acad Sci 105: 17867-17871.

Rumpho ME, Pelletreau KN, Moustafa A, Bhattacharya D. 2011. The making of a photosynthetic animal. J Exp Biol 214: $303-311$.

Schimper AFW. 1883. Über die Entwicklung der Chlorophyllkörner und Farbkörper. Bot Zeitung 41: 105-114, 121-131, 137-146, 153-162.

Schleiff E, Jelic M, Soll J. 2003a. A GTP-driven motor moves proteins across the outer envelope of chloroplasts. Proc Natl Acad Sci 100: 4604-4609.

Schleiff E, Soll J, Kuchler M, Kuhlbrandt W, Harrer R. 2003b. Characterization of the translocon of the outer envelope of chloroplasts. J Cell Biol 160: 541-551. 
Schopf JW. 1993. Microfossils of the early archaean apex chert: New evidence of the anitquity of life. Science 260: 640-646.

Shi LX, Theg SM. 2013. The chloroplast protein import system: From algae to trees. Biochim Biophys Acta 1833: 314-331.

Shih PM, Matzke NJ. 2013. Primary endosymbiosis events date to the later Proterozoic with cross-calibrated phylogenetic dating of duplicated ATPase proteins. Proc Natl Acad Sci 110: 12355-12360.

Smith DR. 2011. Extending the limited transfer window hypothesis to inter-organelle DNA migration. Genome Biol Evol 3: 743-748.

Smith DR, Crosby K, Lee RW. 2011. Correlation between nuclear plastid DNA abundance and plastid number supports the limited transfer window hypothesis. Genome Biol Evol 3: 365-371.

Stephens RS, Kalman S, Lammel C, Fan J, Marathe R, Aravind L, Mitchell W, Olinger L, Tatusov RL, Zhao Q, et al. 1998. Genome sequence of an obligate intracellular pathogen of humans: Chlamydia trachomatis. Science 282: $754-759$.

Terbush AD, Yoshida Y, Osteryoung KW. 2013. FtsZ in chloroplast division: Structure, function and evolution. Curr Opin Cell Biol 25: 461-470.

Tripp J, Hahn A, Koenig P, Flinner N, Bublak D, Brouwer EM, Ertel F, Mirus O, Sinning I, Tews I, et al. 2012. Struc- ture and conservation of the periplasmic targeting factor Tic22 protein from plants and cyanobacteria. J Biol Chem 287: 24164-24173.

Wagele H, Deusch O, Handeler K, Martin R, Schmitt V, Christa G, Pinzger B, Gould SB, Dagan T, KlussmannKolb A, et al. 2011. Transcriptomic evidence that longevity of acquired plastids in the photosynthetic slugs Elysia timida and Plakobranchus ocellatus does not entail lateral transfer of algal nuclear genes. Mol Biol Evol 28: 699-706.

Walter M, Buick R, Dunlop J. 1980. Stromatolites 3,4003,500 Myr old from the North Pole area, Western Australia. Nature 284: 443-445.

Weber AP, Linka N. 2011. Connecting the plastid: Transporters of the plastid envelope and their role in linking plastidial with cytosolic metabolism. Annu Rev Plant Biol 62: 53-77.

Weber AP, Osteryoung KW. 2010. From endosymbiosis to synthetic photosynthetic life. Plant Physiol 154: 593-597.

Weber AP, Linka M, Bhattacharya D. 2006. Single, ancient origin of a plastid metabolite translocator family in Plantae from an endomembrane-derived ancestor. Eukaryot Cell 5: 609-612.

Yang Y, Sage TL, Liu Y, Ahmad TR, Marshall WF, Shiu SH, Froehlich JE, Imre KM, Osteryoung KW. 2011. CLUMPED CHLOROPLASTS 1 is required for plastid separation in Arabidopsis. Proc Natl Acad Sci 108: 18530-18535. 


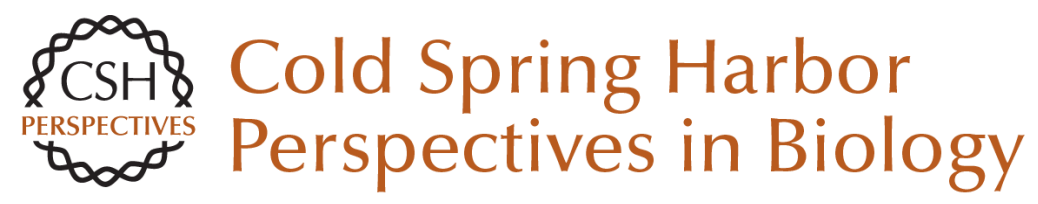

\section{Origin and Evolution of Plastids and Photosynthesis in Eukaryotes}

Geoffrey I. McFadden

Cold Spring Harb Perspect Biol 2014; doi: 10.1101/cshperspect.a016105

Subject Collection The Origin and Evolution of Eukaryotes

The Persistent Contributions of RNA to Eukaryotic Gen(om)e Architecture and Cellular Function Jürgen Brosius

Green Algae and the Origins of Multicellularity in the Plant Kingdom James G. Umen

The Archaeal Legacy of Eukaryotes: A

Phylogenomic Perspective

Lionel Guy, Jimmy H. Saw and Thijs J.G. Ettema

Origin and Evolution of the Self-Organizing Cytoskeleton in the Network of Eukaryotic Organelles Gáspár Jékely

On the Age of Eukaryotes: Evaluating Evidence from Fossils and Molecular Clocks Laura Eme, Susan C. Sharpe, Matthew W. Brown, et al.

Origin of Spliceosomal Introns and Alternative Splicing Manuel Irimia and Scott William Roy

Protein and DNA Modifications: Evolutionary Imprints of Bacterial Biochemical Diversification and Geochemistry on the Provenance of Eukaryotic Epigenetics

L. Aravind, A. Maxwell Burroughs, Dapeng Zhang, et al.
Eukaryotic Origins: How and When Was the Mitochondrion Acquired?

Anthony M. Poole and Simonetta Gribaldo

Bacterial Influences on Animal Origins Rosanna A. Alegado and Nicole King

Missing Pieces of an Ancient Puzzle: Evolution of the Eukaryotic Membrane-Trafficking System Alexander Schlacht, Emily K. Herman, Mary J. Klute, et al.

The Neomuran Revolution and Phagotrophic Origin of Eukaryotes and Cilia in the Light of Intracellular Coevolution and a Revised Tree of Life

Thomas Cavalier-Smith

Protein Targeting and Transport as a Necessary

Consequence of Increased Cellular Complexity Maik S. Sommer and Enrico Schleiff

How Natural a Kind Is "Eukaryote?" W. Ford Doolittle

What Was the Real Contribution of Endosymbionts to the Eukaryotic Nucleus? Insights from Photosynthetic Eukaryotes David Moreira and Philippe Deschamps

For additional articles in this collection, see http://cshperspectives.cshlp.org/cgi/collection/

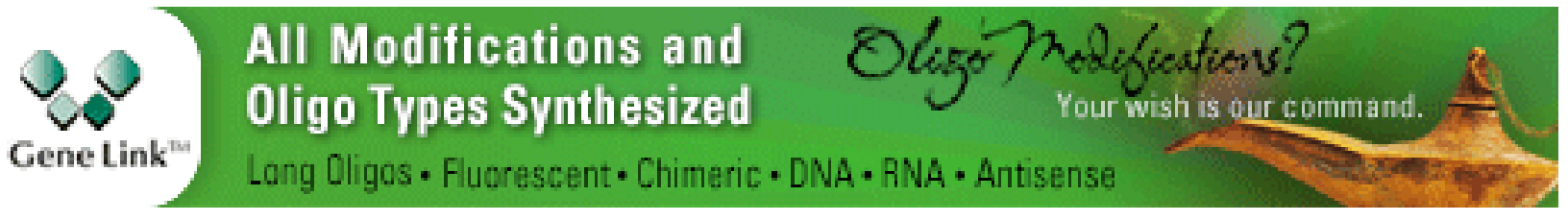


The Eukaryotic Tree of Life from a Global Phylogenomic Perspective Fabien Burki
Bioenergetic Constraints on the Evolution of Complex Life

Nick Lane

For additional articles in this collection, see http://cshperspectives.cshlp.org/cgi/collection/

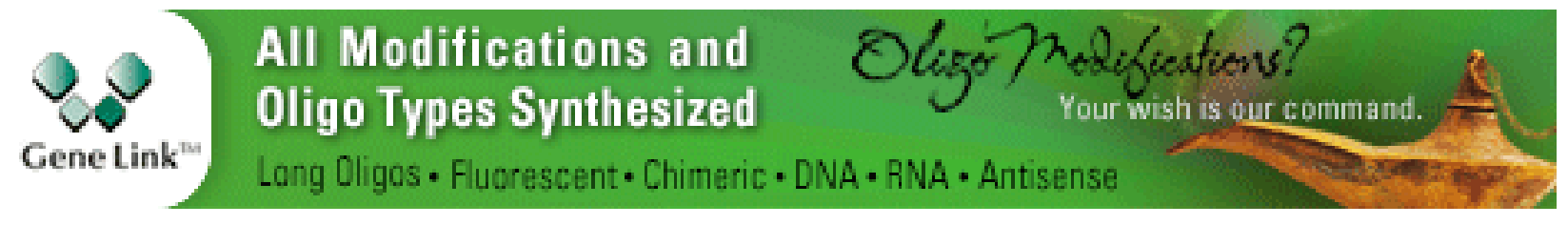

Copyright @ 2014 Cold Spring Harbor Laboratory Press; all rights reserved 